Published in Bulletin of Hispanic Studies, Volume 96, Issue 6, pp. 641-653 published by

Liverpool University Press: https://doi.org/10.3828/bhs.2019.38

\title{
Women and Haunted Houses in the Films of Jaume Balagueró: The Nightmares of
}

\section{Presence}

\section{Ann Davies}

\section{University of Stirling}

Abstract

Jaume Balagueró has developed a successful resumé of horror films that show a decided preference for the classic Gothic motif of the haunted house and the Gothic heroine who investigates its interior. This paper touches first on the Derridean concept of 'dreams of presence' (as theorized by cultural geographer Mitch Rose), in order to propose the 'nightmares of presence' in which the relationship, the call to care or commitment, between the subject and the space in which the subject dwells or moves is Gothicised but nonetheless remains to tie the subject to the space concerned. It then focuses on Balagueró's Los sin nombre, Fragile and [REC] to consider three very different Gothic heroines: the mother of a dead daughter, a nurse in a children's hospital, and a television reporter. The antagonistic call to care of the 'nightmare of presence' will be used to interrogate spatial aspects of the Gothic heroine.

Keywords: Jaume Balagueró; haunted house; Spanish Gothic; Spanish horror; Spanish film

Jaume Balagueró ha desarrollado un grupo de películas exitosas que demuestra una preferencia hacia el escenario clásico de lo gótico, la casa encantada tanto como la heroína gótica que la investiga. Este ensayo estudia en primer lugar el concepto derrideano de 'los sueños de presencia' (según la teoría de geógrafo cultural Mitch Rose), para proponer las 'pesadillas de presencia' en que el vínculo, la llamada a compromiso, entre el sujeto y el espacio en que se mueve o que habita, llega a ser gotizado; pero que fija al sujeto en el espacio relevante. El argumento se enfoca 
en Los sin nombre, Fragile y [REC] para considerar tres heroinas distintas: la madre de una hija muerta, una enfermera en un hospital para niños, y una locutora para un programa televisivo. La llamada antagonista de la pesadilla de presencia se usa para interrogar los aspectos espaciales de la heroína gótica.

Keywords: Jaume Balagueró; casa encantada; gótico español; cine de terror español; cine español

The haunted house has perhaps become all too familiar to us in its very uncanniness. It has long formed a staple of horror and Gothic texts, refracting the decadence of aristocracy and wealth, the corruption of the patriarchal system and the failure of middle-class aspiration. We might assume as a result that the haunted house itself is an exhausted symbol that coincides with the exhaustion of the Gothic itself as claimed by Fred Botting: 'An inhuman future is shrouded in old Gothic trappings emptied of any strong charge: past images and forms are worn too thin to veil the gaping hole of objectless anxiety' (Botting 2002, 298). As regards the haunted house more specifically, David Punter laments that it has little new to tell us. Of David Lindsay's The Haunted Woman, which was published as far back as 1922, he observes that 'the remarkable thing, perhaps, is that the apparatus of haunted houses, mysterious staircases and distant music can still be made to say anything at all' (Punter 1996, 94). If the motif of the haunted house was already tired by 1922, it would seem that, nearly a hundred years later, this motif must be even more wrung dry of meaning.

Yet the motif still persists, and is indeed becoming common in recent Spanish film. A possible explanation for this persistence both within and beyond Spanish cinema is the concept of recuperation of national traumas, in which the house functions as a 
metaphor for the nation; so that while the motif of the house does not change, the traumas experienced by a nation do. In the Spanish case, the national trauma concerned in the Spanish Civil War and the ensuing Franco dictatorship. There are, however, difficulties with an insistence on such an interpretation (see Davies 2016, ch. 4). One difficulty is that confining interpretations to national trauma is that other traumas and tensions run the risk of neglect. One such tension, that has endured along with the haunted house, is that of gender and the relationship of women to domestic spaces. It is this tension that I aim to explore here. Female protagonism, and the complex relationship of women with the spaces that aim to confine them, has been a staple of the Gothic since the novels of Anne Radcliffe and a perennial feature of Anglophone Gothic filmmaking. The resurgence of Spanish horror since the turn of the century has brought these motifs into greater prominence, as a result of the strong influence of Anglophone horror on the genre in Spain. An interest in international market success has also been important, though this has of course been true of Spanish horror since the earlier resurgence in the late 60 s and early 70 s. The result is a number of films that feature women and spooky houses: for example, The Others (Alejandro Amenábar, 2001), Los ojos de Julia (Julia’s Eyes, Guillem Morales, 2011), El orfanato (The Orphanage, J. A. Bayona, 2007), NO-DO (The Haunting, Elio Quiroga, 2009), La cara oculta (The Hidden Face, Andi Baiz, 2011).

Perhaps the greatest proponent of this trend, however, is the Catalan horror director Jaume Balguero, who has made a particular fetish of the haunted house in his films and, in the case of [REC] (codirected with Paco Plaza, 2007), scored notable critical commercial success in so doing. Balagueró formed a crucial part of The Fantastic 
Factory, a Spanish production company whose policy was to make both low-budget and auteurist films in a bid for commercial fantasy and horror. More particularly, Balagueró's work reveals a fixation with haunted buildings: they feature in most of his films: Darkness, Los sin nombre (The Nameless, 1999), Fragile (Frágiles 2005) and the first two [REC] films (2007, 2009), Mientras duermas (Sleep Tight, 2011) and even the short film Para entrar a vivir (To Let, 2006), part of the Fantastic Factory's suite of films by well-known horror directors, Películas para no dormir (Films to Keep You Awake). The only exceptions might be the $[R E C]$ sequels that gradually move the action away from the original haunted house in Barcelona. This paper focuses on some of Balaguero's work, not in order to carry out an auteurist study, but to consider how the films concerned reveal something of how the Gothic brings into question the relationship between women and home space, and how the notion of 'dwelling', with its varied meanings, is linked to the perpetuation of the Gothic house through Balagueró's work.

The ambiguous ideal of the house

Another reason for the perpetuation of the haunted house, and the complex relationships of women with the house, may lie in the fact that the positive values assigned to the notion of a house are equally persistent. In his classic The Poetics of Space, Gaston Bachelard focuses on the more benign symbolism that the idea of a house may provide. He argues that 'A house constitutes a body of images that give mankind proofs or illusions of stability' (Bachelard 2014, 38). Bachelard includes the term 'illusions' which already implies that the stability of the house may be more imagined than real; but Bachelard skips rapidly over the potential threat, and his 
remains a fairly lyric portrait of the house. Of course he is not alone in this: the idea of the house carries many overtones including those of security, shelter, prosperity, and nurture. It also symbolizes family and personal relationships: Bachelard comments that 'The house, even more than the landscape, is a "psychic state", and even when reproduced as it appears from the outside, it bespeaks intimacy' (91). We know, however, that the house contains other, more malign meanings, which feature heavily in the Gothic: it can represent imprisonment, entrapment, violence, abuse, patriarchal control and perhaps above all secrecy, for one of the purposes of the house is to hide these family secrets from the public gaze. Jack Morgan considers the house in terms of its separation from the rest of the community. 'The familiar gothic pattern situates an aristocratic dwelling high above the vulgar village, radically exclusive, cut off from scrutiny and normal moral conventions, and immune to the ordinary reach of law' (Morgan 2002, 181). Changes have been rung on this traditional pattern, as we shall see, but even in contemporary texts with contemporary settings, this pattern remains remarkably persistent. If the house incubates dark secrets which the protagonists take pains to expose, we in turn take pleasure in both the process of uncovering the secret and the dwelling on the secret in morbid fascination. The triple sense of dwelling underscores the ambiguity of the house: dwelling means on one level quite simply a place where people live, but it also refers to the idea of lingering and, in a further twist, a sense of obsession in the constant return to the notion of the haunted house that appears in so many texts. I will be referring to all three meanings in this paper.

The house of course has also traditionally had particular resonance for women as a space of labour and confinement. Andrew Hock Soon Ng, writing precisely on the 
theme of women and haunted houses, refers to 'the traditional link between the female subject and domestic space [...] women, in general, tend to spend more time at home than men do, and are thus more intimately connected, for better or worse, to its interiority' $(2015,10)$. Nonetheless $\mathrm{Ng}$ argues that this link can be destabilized and problematized. The meaning of house and home is a particularly ambivalent one for women: it can for instance be the site where the woman is most valued and yet also a place of work rather than the place of rest and relaxation that it is for others. And while the home has also been the place where the woman remains safe from the perils of the outside world, all too often she might be more at risk when inside the house, the victim of domestic violence. As Mark Wigley observes:

The sense of security associated with the material space of the house that philosophy draws on can never be detached from the violent subordination of the feminine $[\ldots]$ The house is not simply the site of a particular subordination, a particular kind of violence. It is the very principle of violence. To dominate is always to house, to place in the domus. Domination is domestication (Wigley 1993.)

The rise of $20^{\text {th }}$-century feminism has more explicitly refigured the house in terms of a domestic prison for women, an ironic rendering that goes against the association of houses with shelter, with family life, with domestic happiness, and perhaps also with economic aspiration. Fortunately, at least in Gothic texts, women are likely to exercise some form of proactivity even within a limited sphere of action. I am referring to the Gothic heroine, or in its cinematic version the Final Girl theorized by Carol Clover 
(1992). This is the central female figure who resists the villain or monster, survives the terror inflicted on her, and uncovers the secret of what Clover calls the Terrible Place. In the process, they commonly explore the space that holds the mystery.

The nightmares of presence

Before focusing on the specific texts I aim to consider, which are some of the films of Jaume Balagueró, I would like to end this theoretical introduction by introducing the concept of my subtitle, the nightmares of presence, which is a concept I derive from the cultural geographer Mitch Rose's concept of 'dreams of presence', which he in turn has derived from Jacques Derrida. Rose's conceptualization aims to refigure the relationship between landscape and culture as process rather than as a static structure and moreover, as a process that never comes to completion. Dreams of presence:

are things that do not exist and are, strictly speaking, impossible, And yet they exist as possibilities, as things held out to us as possible at the horizon of our being (Rose 2006, 542).

Rose wishes to emphasise what he terms 'the call of care', 'A call that is defined by its direction - that is, by its orientation towards attachment - rather than in terms of where it arrives (culture, community, nationality, etc)' (543). How does this work in terms of landscape, space and place? According to Rose: 
This is a landscape that is being not constructed but engaged with [...] It is a landscape that speaks to people, beckoning them to care. In this sense, it engenders dreams of presence (expressions of care) that allow those living within the landscape to imagine, cultivate, and move towards their world (and their place within it) as present and, in the process, to experience it more intensively (549).

The terms Rose uses - the very notion of a 'call of care' - suggest a benign direction and benign desires which bring us back not far from the lyricism of Bachelard. As Rose adds, 'It is a call to invest in, cultivate and nurture' (543), and this phrase brings us quite close to the initial symbolism of the house with which I began. What I am proposing is a twist on Rose's concept in order to hypothesize, not a dream of presence but a nightmare of presence. $\mathrm{Ng}$ argues that: 'the Gothic is where the subject/space dialectic customarily finds its most extreme and potent expressions' $(\mathrm{Ng} 2015,18)$. Taking Rose's and Ng's ideas together, then, I am arguing that the nightmare of presence is Rose's call of care for what is not simply impossible but inadmissible, for what threatens both meaningfulness and subjectivity itself; the call to care at its most extreme. In the case of the house, the nightmares of presence is a way of expressing how the house actually threatens our subjective meaning. Since this is a process that is never finished, we return again and again to the idea of the haunted house, in a process that is itself a constant call of commitment, but also a dwelling on a dwelling. Balagueró himself demonstrates this repetition and return to the house that is part of the nightmare of presence. 
Julio Ángel Olivares Merino has observed a unified approach to setting in Balagueró's films, talking of a 'sentido de lo malsano que contamina todo en los paisajes de ciudad, los entornos urbanos, en especial los inmuebles' (Olivares Merino 2011, 44), and later argues:

los espacios balaguerianos son perímetros de la enajenación en los que, lejos de reconocerse - lugares de pertenencia -, los actantes se experimentan fugazmente, perpetuando su inercia de éxodo y búsqueda imposible del ayer (58).

These, then, are landscapes of alienation and entrapment, landscapes where any call to care could only be distorted or antagonistic. In commenting on Balagueró's settings, Olivares Merino takes note of an 'ausencia del hogar' $(2011,44)$, thus positing a contrast between the bleak spaces of which he writes and the sense of the house as home that Bachelard describes. And yet, there may not be homes in these films in Bachelard's sense, but there are certainly houses, and all Gothic ones plagued by a dark family secret. The house may be the site of madness and violence visited by fathers on children (Darkness), of disease at the heart of the family (Darkness and [REC]); and more particularly it proves to be a site where women are threatened, by incarceration (Para entrar a vivir), by sexual violation (Mientras duermas), or by a corrupt paternal descent in which female intervention fails (Los sin nombre, Darkness).

The Gothic heroine 
The familiar agency of the Gothic heroine can prove futile, as both the heroines of Darkness and Para entrar a vivir discover. Nonetheless, Balagueró frequently resorts to the Gothic heroine as a figure with which to confront the haunted house, playing with this very sense of agency that the figure supposedly commands in order to tease out the complexity of the relationships between the subject and the house that the subject comes to occupy. What I will focus on here are three films that demonstrate not only a strong relationship of antagonistic care between the Gothic heroine and the house, but a relationship refracted through a parallel relationship of care or commitment between the female protagonist and a monstrous daughter figure: Los sin nombre, Fragile and the first [REC] film. In Los sin nombre the central character is Claudia (Emma Vilasarau), whose daughter Ángela (Jessica del Pozo) was apparently found dead five years before the main action of the film starts. Now a career woman living alone, Claudia begins to receive mysterious phone messages purporting to be from her daughter. The messages lead her to a deserted old mansion by the sea, and later to another house in the woods where her daughter has been held captive. In Fragile the central character is Amy (Calista Flockhart), an American nurse who comes to the hospital of Mercy Falls on the Isle of Wight to look after sick children. She soon discovers that the hospital is haunted and she explores the building in order to find out why and to try to stop the haunting. Finally in [REC], Ángela (Manuela Velasco) is a TV reporter for a programme called Mientras usted duerme (While You're Asleep), that explores night-time activity in Barcelona. On this occasion she and her cameraman follow a fire crew to a house in which they are all subsequently quarantined owing to an outbreak of what looks remarkably like zombieism. All three of the protagonists fit to some degree the model of the traditional inquisitive Gothic heroine exploring the castles and convents in 
which she is trapped, or her near cousin the Final Girl, who challenges the monster. This pattern appears elsewhere in Balagueró's work (Regina in Darkness, Clara in Para entrar a vivir): what distinguishes these three films is the role of the monster as reflected through a daughter figure or female child. I shall say more about this daughter figure below.

In the houses of all three films I discuss here, the female protagonist has come from the outside, in a suggestion of movement towards that echoes Rose's conceptualization of deliberate engagement with their surroundings. In Claudia's case this is literally so in that the camera follows her from the beach and entering the house in a sequence that evokes the usual suspense in moving through haunted spaces (have we ever stopped to think about the slow speed at which people move through a haunted house? Would our instinct not to be to move as quickly as possible? Here we have an example of a double meaning of dwelling or lingering). Amy and Ángela also are to be found in sequences that show them moving from the exterior to the interior: Amy's status as an American renders her as even more of an outsider in a film set in the UK, and this is underscored by the opening credit sequence as she arrives on the Isle of Wight ferry. Ángela is also seen as moving from outside to inside as she follows the fire crew, reporting on their night shift. She is an intruder in being neither a resident of the Barcelona house nor an authority figure trying to deal with the outbreak, and often she and her cameraman Pablo get in the way. Nonetheless these outsiders also become insiders. Ángela never escapes this house (in this film at least: she does, however, reappear in [REC]4). The last we see of her is as she is dragged away into the darkness by a new variant of Gilbert and Gubar's madwoman in the attic (Gilbert and Gubar 
2000), the Medeiros child (Javier Botet) who seems to be the source of the zombie infection and is indeed living in the attic. (I use the term 'living' loosely here: it is a form of dwelling rather than living, in which the monster both inhabits and lingers). Amy appears to escape death as the hospital collapses, and appears to get away. However, she ends the film recovering in another hospital building and haunted by a ghost, a situation that diminishes the sense of escape. Claudia's position is more openended in that ultimately nothing happens to her as such. She finds that her daughter has been co-opted into a cult and turned evil: the daughter shoots herself and the film ends there. But precisely because it does end there, we never see Claudia leave the house: we have no idea what she does next because the film does not say. It ends instead with the illusion of the happy family in the open space of the beach, captured in an old home movie, a contrast that simply serves to underline the destruction of the family unit and the entrapment in an old decrepit house.

The Gothic heroine and the damaged daughter figure

In one sense, the movement of Gothic heroines through these buildings offers an ironic contrast to the image of the house as the centre of domestic bliss; and yet in our three films such a notion is undermined before it can take root. Claudia's own flat is a cold space whose sole purpose appears to be the mourning of her dead daughter; Amy has one cold room in the Mercy Falls hospital and does not spend much time there (the only scene in her room is on her first arrival: never after that point does she spend any time in private space); Ángela is presented in career terms with no sense of a home or private life. As Agnieszka Soltysik Monnet observes, Ángela is 'a professional public 
woman, young, beautiful, poised and ambitious', (Monnet 2015, 150): Monnet goes on to analyse how Ángela is positioned as a body constantly on display. All three women, however, share a focal point that connects both with the notion of the house as a site of family relations and with older Gothic ideas about imprisoning women. This is the daughter figure referred to earlier: a figure I am specifically terming the damaged daughter. The figure concerned is not necessarily an actual daughter, but is a female child who is damaged, disfigured or diseased in some way; and is imprisoned or trapped in the house investigated by the protagonist. The figure of the damaged daughter coincides to a great extent with Monnet's position concerning changes in representations of female monstrosity:

The new female monsters are not overtly sexual, at least not initially, because they are too old, or more often, too young. If the power of the traditional sexualized female monster lies in her deadly beauty, the power of the recent female monster lies in the way we expect her to be helpless and vulnerable. When she turns out to be violent and dangerous, much of her dramatic effectiveness comes from the surprise and uncanniness created by this reversal (Monnet 2015, 152).

Such a reading applies neatly to [REC], about which Monnet is specifically writing; though Monnet also observes that to some extent the identity of the Medeiros child precisely as a child is anomalous, since she must be round about 20 when the film's action takes place (153). The body we see appears to be of adult size, strongly implying that the child has since grown. Nonetheless, as Monnet goes on to argue, the 
Medeiros's child's monstrosity arises from the abuse she received as a child: or, we could say, the label she is given derives from her historical identity. Her own story, which Ángela begins to tell and which will continue in [REC]2, is all about her status as a vulnerable child. The Ángela of Los sin nombre, Claudia's daughter, likewise is vulnerable, having been subject to overtly patriarchal abuse (that of her father), but this Ángela is also violent and dangerous, taunting her mother and threatening her with a gun. Monstrosity is, however, more diffuse in Fragile, as the actual monster proves not to be a child but another adult (nonetheless, the other children call her 'the mechanical girl'). Damaged children saturate the film, however, in terms of both the present and the former patients who are all frail in some way, and some of whom have also been abused and/or held against their will.

While the protagonist is impelled to respond to the damaged daughter in some way, that response does not have to be maternal, though it often in fact is: the crucial element is, however, that the protagonist recognizes the damaged daughter figure as vital to the explanation of whatever is haunting the house. So Claudia's daughter is lame and imprisoned in the house by her own father: Claudia's search for her is a clearly maternal quest and yet also a quest for solving an occult mystery of ultimate evil. Amy shows a maternal care towards Maggie (Yasmin Murphy), a terminally ill child imprisoned both by her own ill health and by the ghost of Charlotte (Karmeta Cervera) who wants to keep her in hospital. Amy also pursues Charlotte herself in the belief that Charlotte is the ghost of a dead child, though this turns out to be false - the dead child is called Mandy (Ivana Baquero) and Charlotte was her nurse: but Mandy, too, was a sick child who was further damaged when alive, literally so, by Charlotte. Finally Ángela 
in $[R E C]$ demonstrates no maternal feeling towards the Medeiros child but nonetheless discovers that this child is the clue to the mysterious zombie outbreak, since the child herself was infected with the zombie virus and shut away in the attic. In addition, as Monnet notes, she also bears the marks of the occult experiments performed on her: 'Her violent body is all the more terrifying because it bears the visible signs of torture and neglect: emaciation, deformity and grotesque scars' (153). As we can see from this, Balagueró is adept at finding permutations that nonetheless demonstrate a continuing link between the house and the female child figure.

The house as a nightmare of presence

It is this link that I want to focus on as the channel through which the nightmare of presence is enacted. The house becoming the landscape through which an ultimately antagonistic call of care continues to come into being without ever fully being realized, and the point at which our protagonists' engagement with their surroundings becomes clear. In order to examine this I now want to talk more about dwelling, the point I raised earlier. I will begin by considering [REC] as this might seem like a counterintuitive example. In [REC] the notion of dwelling as lingering seems to be contradicted by the frenetic speed at which Ángela and Pablo (Pablo Rosso, voice by Javier Coromina) hurtle round the house, underscored by Pablo's point of view as the cameraman - the whole of the action is filmed through his camera. Nonetheless the action leads them to all corners of the house, while the claustrophobia of movement through the narrow passageways (combined with a sense of crowding from the residents, at least in the first half of the film), draws attention to the walls that hem the 
characters in. Repeatedly we are given the sense of imprisonment: the characters are trapped inside the house, and the speed of the action serves ironically simply to underscore the impossibility of escape: for all the frantic action nobody ever really goes anywhere. In addition, there are two sequences in which the details of living spaces are minutely explored. In the first of these, Ángela is looking for some keys in the flat of the residents' community president. The camera picks up small details such as the switched on TV and the half-eaten dinner, while it intermittently picks up Ángela rootling around furniture and drawers to find the key. This scene acts as an exercise in reading clues from a room - the president was called away to the zombie crisis in the middle of eating his dinner - that sets the audience up to read the climactic second example of a minute exploration of living space. The second such scene takes place in the attic, where Ángela comes into her own as a sort of Final Girl, stopping her rush to find a way out of the house in order to linger on the news clippings pinned to the walls, as well as the taped message lying underneath a pile of papers, that introduce the Medeiros girl and give a clue to the mystery.

Fragile also stages its climactic scene in the attic, which Amy visits twice. From an early stage the film posits the hospital's second floor, closed off since Charlotte' suicide, as the site of horror. Even before she visits it, Amy is conscious of it: she often looks at the ceiling in response to unexplained noises. The first time that Amy ascends to the second floor, with its sickly green walls and cold light, she finds the floor dotted with used toys, as well as an old film reel in which a child (Mandy) is being treated for brittle bone disease, her legs encased in iron supports. The discovery of the film reel coincides with the onset of ominous creaking from the building structure. Amy must later return 
to the second floor to rescue Maggie, who has been seized by Charlotte. As Amy snatches Maggie, the floor gives way, the corridors start to collapse and objects fall to the floor. As they descend through the trapdoor a pile of rubble comes through after them, killing Maggie and critically injuring Amy herself.

It is notable that the solution to the mystery is tied up with the collapse of the hospital building, but again, it is also uncovered by Amy's dwelling in the space. It is Amy who constantly pauses to listen to the building: she moves in a less hurried manner than the other hospital staff, in order to take time to think about what the house is trying to express through its creaking and groaning. And despite the horror that lurks upstairs, Amy takes her time in this space, picking up and testing out individual toys that demonstrate how the haunting of this space is bound up with the love of children. Indeed, the fact that Amy does take her time to explore each old toy suggests how far she is engaged with the meaning of this haunted house and that she is the right person to solve the problem of haunting. She is also the right person to rescue Maggie, both because of her care but also because she is able to negotiate this inadmissible space.

Like Amy, Claudia also enters a haunted space twice, and moves slowly in order to determine what each house can tell her about her daughter's whereabouts. Los sin nombre is packed with gloomy dwelling spaces, underscored by the fact that the film has a black and white look even though it is shot in colour. The homes of both Claudia and Massera (Karra Elejalde), the former police detective who helps her, are places of mourning for lost loved ones (the detective's wife has died), while Claudia's flat is a cold, sterile space (apart from the daughter's bedroom that acts as a shrine to her 
memory and provides the only notes of colour in the flat). Other homes visited during the investigation are decrepit, shot in a sickly green that foreshadows the hospital walls of Mercy Falls in Fragile. The house that Claudia explores in most detail, however, has already been captured on the home videos of herself and her daughter playing by the beach. It is derelict - shot in cold light with an emphasis on greys and whites - but nonetheless imposing, dominating the screen as Claudia approaches it. As with Fragile and [REC] Claudia finds a room that gives her clues to the mystery: a room full of junk, including papers and a dead bird in a cage. A second room holds a round container which she opens. At this point we cut to another scene, leaving us in suspense as to what is in the container. This draws attention to another meaning of dwelling: of course, Gothic heroines often move slowly around their spaces for the practical reason of heightening the tension and interest for the audience. What Claudia actually found in the earlier scene was an orthopaedic boot that belonged to her daughter. This sequence suggests that it is only when Claudia takes the time to engage with her surroundings that she is able to move on and find her daughter within a dwelling space. The orthopaedic boot found among the debris of the house marks a clear equation of the daughter with the house as physical space.

Our three Gothic heroines are thus dwelling on the dwelling, looking at, touching and listening to the decaying fabric and the decrepit household contents that lie within. It is this dwelling, in the sense of lingering, that suggests an engagement with their surroundings and therefore a nightmare of presence, in that they are interacting with something that is not only an impossible possibility but an inadmissible one. And the focus of that inadmissibility is the damaged daughter figure who both attracts and 
repels, being monstrous. The damage done to the daughter figure and the decay of the house parallel each other; and by engaging with the fabric, fixtures and fittings of each building our Gothic heroines bring to light what is not only impossible but inadmissible. This is not simply the monstrosity, decay and death but also the call of care, of commitment, to these things that each protagonist shows. It is nonetheless a commitment that imperils subjectivity and meaning, even life, for each heroine even as they appear to find meaning in the physical space of the house.

The obsession with haunted houses

As regards the final sense of dwelling with which I began, the sense of obsession, I would argue that Balagueró's whole oeuvre suggests this through the constant return to the motif of the haunted house, suggesting a repetition without resolution. The work of Rebecca E. Martin (1998) on repetition, pleasure, and the Gothic can help us here. One of the pleasures she refers to is the desire to keep reading (or in this case keep viewing), so that consumption of the Gothic becomes a serial pleasure, but always a pleasure of anticipation that is never quite satisfied:

The Gothic provokes an 'unsuspected visual pleasure' in the reader with images that promise to show and promise to display the 'truth' of whatever the reader wants to see [...] If one image does not fulfill expectations, the next one may; repetition offers an endless possibility for the search for 'truth' in whatever form it is desired (Martin 1998, 82). 
The fact that the compulsion towards the haunted house is never fully satisfied is precisely the point: it demonstrates the nightmare of presence in that the call of care to what is monstrous will never be completed or finally resolved. Our obsession is our own nightmare of presence, a commitment to the inadmissible dwelling in the haunted house.

Going back to my starting point, then - Punter's comments on the potential exhaustion of the haunted house motif - the concept of the nightmares of presence suggests that novelty may not in fact be the point. It is the repetition of the motif that draws our attention to another permutation on the idea of dwelling: our own obsession with haunted houses. Their constant repetition in texts suggests our own nightmare of presence, an engagement with landscape at its most extreme. If, in Balagueró's films, it is the woman who is charged with the call of care for the house and the daughter figure, his contribution to the repetition of the haunted house motif, and our pleasure in and engagement with it, offers a nightmare of presence in which our unsatisfied desires for the inadmissible is not gender bound. Film, of course, offers us opportunities for both our own dreams and nightmares of presence, for our engagement with the landscape is always mediated in some measure, even if we experience the landscape directly. Such experiences are formed in part through our previous encounters with landscape, many of which will have come through cultural texts as much as, if not more than, our own physical presence within a landscape. As regards haunted houses, our direct experience would presumably be limited at best, even if we believe that houses can be haunted in reality. Cultural texts therefore must play a crucial role in the formation of our own call to care for the haunted house but, 
as Rose, argues, this call to care is always a movement towards and never a point of arrival. Hence the repetition of the motif: our concern for the house and the dark secrets it may contain can never be completed or cast aside. In that sense, Punter's point about exhaustion becomes moot, for our concern can never be exhausted.

In his own essay on [REC], Víctor Pueyo observes that haunted houses are once again prolific in cinema and says: 'the question should be: What is a haunted house? And the answer is always a historical one' (Pueyo 2017, 148). I am not so sure we can be that categorical. While Pueyo's subsequent argument - interpretations linked to problems in housing markets - is persuasive, historical explanations tend to submerge the vexed question of repetition. But in particular they also submerge the specific role of women, always placed precariously as regards history since, in their relation to the house, they frequently lack historical agency. A danger with Rose's theory of the call to care and the nightmares of presence is the fact that care itself can be a gendered word, as caring in many guises often falls to women. Care and commitment, as regards haunted houses, are all too often the burden that women must bear: women become the 'primary carer' in a new sense, in that they must drive the call to care even if men are around to help (as Massera the detective does in Los sin nombre, Pablo in [REC] and Robert (Richard Roxburgh) in Fragile). Not all haunted house films inevitably do this but a surprising number stick to this formula; and contemporary Spanish Gothic cinema includes some notable examples. El orfanato (The Orphange, J. A. Bayona 2007), The Others (Alejandro Amenábar, 2001) and NO-DO (The Haunting, Elio Quiroga, 2009) all exemplify this trend. Likewise this care, the need to commit oneself to the house in order to resolve the haunting, does not necessarily have to involve children but it is striking how many 
do: Balagueró's films themselves regularly feature at least one child playing a significant role, as do the other examples mentioned above. And all too frequently these children are the victims of violence and abuse, including the damaged daughter figures we have considered here. The nightmares of presence thus risks becoming yet another form of childcare, again traditionally considered woman's work.

In that sense we do not seem to have moved on too far from the sense of the house as a domestic trap, a space for which women are ultimately responsible. In this sense, the nightmare of presence is, as I posited earlier, a way of expressing how the house actually threatens our subjective meaning. As Wigley argues, the house does violence to female subjectivity, and the apparent agency of the Gothic heroine or Final Girl in many Spanish Gothic films becomes simply the agency to do the domestic work. In the end, the nightmare of presence for Balagueró's protagonists may be that they cannot escape their caring responsibilities, and what is truly inadmissible is their inability to escape. Their obsession, and our obsession - the dwelling in all senses - is a desire to clean house while also a desire to escape the need to care, in such terrible circumstances, for ever.

\section{References}

Bachelard, Gaston, 2014 (1964). The Poetics of Space, trans. Maria Jolas (New York: Penguin) 
Botting, Fred, 2002. 'Aftergothic: Consumption, Machines, and Black Holes', in The

Cambridge Companion to Gothic Fiction ed. Jerrold E. Hogle (Cambridge: Cambridge University Press), 277-300.

Clover, Carol J., 1992. Men, Women and Chainsaws: Gender in the Modern Horror Film (Princeton: Princeton University Press)

Davies, Ann, 2016. Contemporary Spanish Gothic (Edinburgh: Edinburgh University Press).

Gilbert, Sandra M. and Susan Gubar, 2000. The Madwoman in the Attic: the Woman Writer and the Nineteenth-Century Literary Imagination. $2^{\text {nd }}$ ed. New Haven: Yale University Press.

Martin, Rebecca E., 1998. '”I Should Like to Spend My Whole Life in Reading It": Repetition and the Pleasure of the Gothic', Journal of Narrative Technique 28/1, 75-90.

Monnet, Agnieszka Soltysik, 2015. 'Body Genres, Night Vision and the Female Monster: REC and the Contemporary Horror Film', in Monstrous Media/Spectral Subjects: Imaging Gothic Fictions from the Nineteenth Century to the Present, eds Fred Botting and Catherine Spooner, eds, (Manchester: Manchester University Press), 143-56.

Morgan, Jack, 2002. The Biology of Horror: Gothic Literature and Film (Carbondale: Southern Illinois University Press) 
Ng, Andrew Hock Soon, 2015. Women and Domestic Space in Contemporary Gothic Narratives: the House as Subject (New York: Palgrave Macmillan).

Olivares Merino, Julio Ángel, 2011. Jaume Balagueró: en nombre de la oscuridad (Madrid: Akal).

Pueyo, Víctor, 2017. 'After the End of History: Horror Cienma in Neoliberal Spain (2002-2013)', in Tracing the Borders of Spanish Horror Cinema and Television ed. Jorge Marí (New York: Routledge), 141-60.

Punter, David, 1996. The Literature of Terror: a History of Gothic Fictions from 1765 to the Present Day, vol. 2: the Modern Gothic (Harlow: Pearson Education)

Rose, Mitch, 2006. 'Gathering "Dreams of Presence”: a Project for the Cultural Landscape', Environment and Planning D: Society and Space 24, 537-54.

Wigley, Mark, 1993. The Architecture of Deconstruction: Derrida's Haunt (Cambridge, Mass.: MIT Press) 